\title{
Original
}

\section{Purification of Thiol-Dependent Collagenolytic Enzyme Isolated from Culture Supernatant of Bacteroides gingivalis 381 and Its Inhibition by Some Serum Components*}

\section{Bacteroides gingivalis の培桊上清中に存在する $\mathrm{SH}$-依存性の}

コラーゲン溶解醉素の精製と血清成分による阻害*

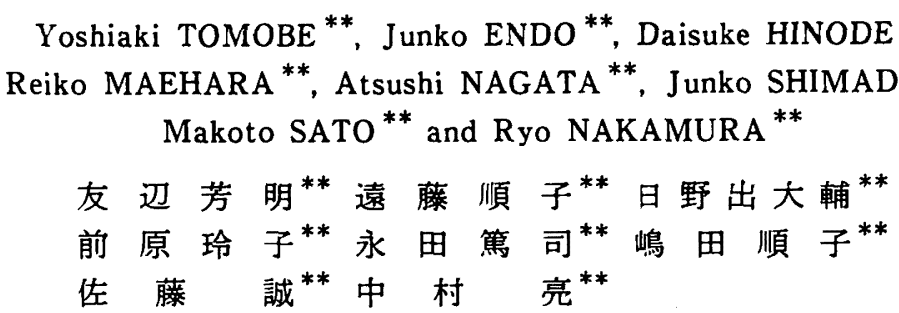

Received June 15, 1987 ; accepted August 10, 1987

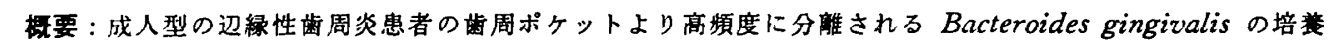

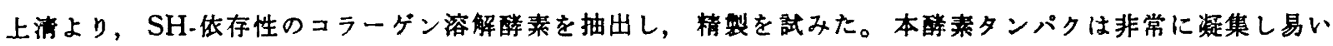
性兵のためイオン吸着クロマトグラフィーが困難であったが，非イオン性の界面活性郕である 1-O-N.Octyl-

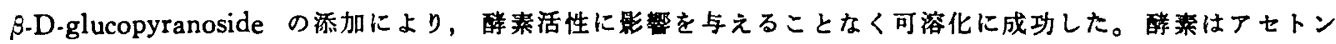
分画, Sepharose CL-6B によるゲル㴼過，1-O-N-Octyl- $\beta$-D-glucopyranoside による可溶化，DEAE-Sephacel カラムクロマトグラフィー等により,タンパク当りの比活性で115倍に部分精製した。部分精製䤃素は 至適 $\mathrm{pH} 7.6 \sim 8.0$ で，等笔点は $\mathrm{pI} 4.4$ と5.5に存在し，SH-依存性は粗䤃と同様に非常に强いことがわか

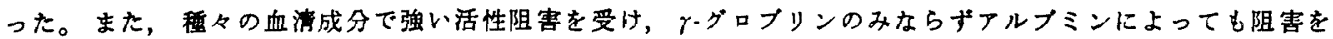
受けることが判明した。このことは齿周ポケット内で, 浸出液中の血清成分が B. gingivalis の病原性を娍 弱させるのに何らかの役割を果たしている可能性を示唆するものである。

Koy words: Collagenolytic enzyme, Bacteroides gingivalis, Serum components

索引用語 : コラーゲン溶解醅素, バクテロイデスジンジバリス，血淟成分

* A part of this study was presented at the 33rd General Session (October, 1984) of Japanese Society for Dental Health

* 本研究の一部は第33回日本口腔衛生学会総会（昭和59年10月）において発表した。

** Department of Preventive Dentistry, School of Dentistry, The University of Tokushima (Director : Prof. Ryo NAKAMURA)

** 徳岛大学齿学部予防歯科学教室（主任：中村 亮教授） 


\section{Introduction}

There are several studies suggesting that enzymes are implicated in the etiology of gingivitis and marginal periodontitis. Some of these are concerned with mechanisms of enzymes which are increased in gingival and periodontal tissues ${ }^{1,2)}$, but a few emphasize the direct function of enzymes which are produced by oral bacteria. ${ }^{3)}$ Among these enzymes, collagenase and protease are thought to be important because of their ability to directly destroy connective tissues. Our previous study" demonstrated that culture media from Bacteroides gingivalis contained collagenolytic enzyme and that the enzyme activity was highly enhanced by the addition of reducing reagents having thiol groups. This enhancement appeared only in the $B$. gingivalis enzyme and not in the enzyme from other Bacteroides species. The same enhancement in protease from $B$. gingivalis was reported by several other groups. ${ }^{5-7)}$ From this point of view, it was suggested that the collagenolytic enzyme produced by $B$. gingivalis was a different type of collagenase from those found in other microorganisms ${ }^{8)}$ and tissues. ${ }^{9-11}$

The collagenolytic enzyme from $B$. gingivalis showed activity in a reduced environment, because $B$. gingivalis is predominant in deep gingival pockets of patients with adult type of periodontal disease. 12-14) This characteristic may be favorable in maintaining the direct function of the enzyme as a pathogen of periodontal disease. For further investigation, isolation and purification of this enzyme are required. However, the large molecules secreted into the bacterial culture medium of $B$. gingivalis possesses strong coaggregating nature which makes it difficult to isolate and purify enzymes.

The purpose of this paper is to describe the isolation and purification of a thiol-dependent collagenolytic enzyme produced by $B$. gingivalis. Inhibition of this enzyme by some serum components also is described.

\section{Materials and Methods}

Bacterial strains : Bacteroides gingivalis 381 was obtained from the State University of New York at Buffalo by the courtesy of Drs. R. J. Genco and J. Slots. It was maintained by weekly transfer on anaerobic basal medium ${ }^{15}$ ) with $5 \%$ sheep blood. Organisms in preculture were grown in anaerobic BHI broth supplemented with yeast extract, vitamin $K_{1}$, and hemin. ${ }^{15}$ ) All cultures were incubated at $37^{\circ} \mathrm{C}$ in an anaerobic box (Forma Scientific, Marietta, Ohio, USA) with an atmosphere of $5 \%$ carbon dioxide and $10 \%$ hydrogen in nitrogen.

Assays of collagenolytic activity: Collagenolytic activity was measured as previously described by Toda et al." ${ }^{14} \mathrm{C}$-Acetylated rat-skin collagen was prepared ${ }^{16-18)}$ and used as substrate for the enzyme assay. The reaction mixture consisted of $0.2 \mathrm{~m} l$ of $0.2 \%{ }^{14} \mathrm{C}$-acetylated collagen solution (about 10,000 $\mathrm{dpm}$ ) in $0.05 \mathrm{M}$ Tris- $\mathrm{HCl}$ buffer $\mathrm{pH} 7.8$, containing $0.2 \mathrm{mM} \mathrm{NaCl}, 5 \mathrm{mM} \mathrm{CaCl} 2$ and $1 \mathrm{mM}$ dithiothreitol (DTT) and aliquots of enzyme preparation. The final volume was made up to $0.4 \mathrm{~m} l$ with the same buffer. After incubation at $35^{\circ} \mathrm{C}$ for $1 \mathrm{~h}$, the reaction was stopped by adding $20 \mu \mathrm{l}$ of $0.4 \mathrm{M}$ ethylene diamine tetraacetate (EDTA) sodium salt, $\mathrm{pH} 7.8$, in dioxiane. The mixture was kept at the same temperature for another $60 \mathrm{~min}$ and then placed at room temperature. The reaction product in the resulting mixture was extracted with $0.4 \mathrm{~m} l$ of dioxiane by vigorous shaking followed by centrifugation at $3,000 \times \mathrm{g}$ for $20 \mathrm{~min}$. Aliquots $(0.5 \mathrm{~m} l)$ of the supernatant was transferred into counting vials which contained ACS II Liquid Counting Scintillant and measured for radioactivity. As a blank for each determination to exclude neutral proteases activity, a parallel reaction mixture included $20 \mathrm{mM}$ EDTA, and the collagenolytic activity was corrected by subtracting the apparent activity of each blank determination. One unit of collagenolytic enzyme was defined as the amount which digested $1 \mu \mathrm{g}$ of 
collagen per $\min$ at $35^{\circ} \mathrm{C}$. Specific activity was expressed as units per $\mathrm{mg}$ protein of enzyme solution. Protein in the sample was estimated by Lowry's method as modified by Hartree. ${ }^{193}$ Recrystallized bovine albumin was used as the standard for protein assay.

Preparation of anti-B. gingivalis serum globulin: Rabbits were immunized with whole cells of B. gingivalis 381 . Cells were formalin-killed and suspended in saline at a density of $20 \mathrm{mg}$ wet weights per $\mathrm{m} l$. Rabbits were injected subcutaneously above the vertebral column with approximately $0.5 \mathrm{~m} l$ of cell suspension incorporated into an equal volume of Freund complete adjuvant. One booster immunization of the same immunogen was carried out 1 month later. Serum was collected approximately one month after the booster immunization. The $r$-globulin fraction was obtained from the serum by high performance liquid chromatography using a Glas Pac TSK DEAE-5PW.

Purification and isolation procedures of collagenolytic enzyme: Preculture of $B$. gingivalis 381 was transferred into $1,500 \mathrm{~m} l$ of the same anaerobic $\mathrm{BHI}$ as used for preculture and cultivated anaerobically at $37^{\circ} \mathrm{C}$ to a stationary phase. The culture was then centrifuged for $15 \mathrm{~min}$ at $10,000 \mathrm{~g}$ and the supernatant was harvested for the following purification. Unless stated otherwise, the centrifugation and all subsequent purification were carried out at $4^{\circ} \mathrm{C}$.

To the culture supernatant $(1,350 \mathrm{~m} l)$, one and a half volume of acetone, which had been chilled to $-20^{\circ} \mathrm{C}$, was added gradually by gentle stirring. The temperature of the mixture was kept at $-2^{\circ} \mathrm{C} \sim$ $-10^{\circ} \mathrm{C}$ during this procedure. The mixture was then centrifuged at $10,000 \mathrm{~g}$ for $30 \mathrm{~min}$ at $-10^{\circ} \mathrm{C}$. The resulting precipitate was dissolved in $40 \mathrm{~m} l$ of $10 \mathrm{mM}$ Tris- $\mathrm{HCl}$ bubber, $\mathrm{pH} 7.4$ containing $1 \mathrm{mM}$ DTT and dialyzed overnight against the same buffer. The dialyzed sample was applied to a Sepharose CL-6B gel column $(5 \times 100 \mathrm{~cm})$ which had been equilibrated with the same buffer. The flow rate was adjusted to $45 \mathrm{~m} l$ per hour and $15 \mathrm{~m} l$ fractions were collected.

The collagenolytic enzyme-active fractions from the gel filtration were collected and centrifuged at $100,000 \mathrm{~g}$ for $120 \mathrm{~min}$. The subsequent sediment was dissolved with $0.8 \% 1$-O-N-octyl- $\beta$-D-glucopyranoside (Oct-Glu) in the above buffer. The mixture was again centrifuged at the same conditions and the supernate was applied to a column $(2.6 \times 50)$ packed with DEAE-Sephacel which had been equilibrated with $10 \mathrm{mM}$ Tris $\mathrm{HCl}$ buffer, $\mathrm{pH} 7.4$, containing $1 \mathrm{mM}$ DTT and $0.8 \%$ Oct-Glu. After the column was washed with $300 \mathrm{~m} l$ of the same buffer, eluation was carried out, in a stepwise manner, by succesive addition of $0.1,0.2$, and $0.4 \mathrm{M} \mathrm{NaCl}$ in the same buffer. The flow rate was adjusted to $30 \mathrm{~m} l$ per hour and the $6 \mathrm{~m} l$ fractions were collected. The absorbance at $280 \mathrm{~nm}$ of the elution was monitored by an ultraviolet absorption meter.

Chemicals and reagents: All reagents used were of analytical grades and generally purchased from Sigma Chemical Co., St. Louis, Mo., U. S. A. $1^{-14} \mathrm{C}$-Acetic anhydride and ACS II Liquid Counting Scintillant were from Amersham/Searle, Arlington Heights Ill., U. S. A., and all serum components were from Miles' Laboratories, Inc., Elkhart, Indiana, U. S. A. I-O-N-Octyl-ş-D-glucopyranoside was purchased from Nakarai Chemicals, Kyoto, Japan.

\section{Results and Discussion}

Table 1 shows the summary of isolation and partial purification of collagenolytic enzyme from culture media of B. gingivalis 381 . In the gel filtration on Sepharose CL-6B, the collagenolytic activity was eluted at the void volume fraction, from which the molecule size of the collagenolytic enzyme was estimated to be more than $1 \times 10^{6}$. However, it was found by the following procedures that this large molecule was due to the aggregation of the proteins secreted into the culture medium by $B$. gingivalis. When the active fraction from gel filtration was applied directly onto a ion-exchange column, the enzyme 
Table 1 Purification of SH-dependent collagenolytic enzyme from Bacteroidts gingivalis 381

\begin{tabular}{lcccccc}
\hline \multicolumn{1}{c}{ Steps } & $\begin{array}{c}\text { Total } \\
\text { volume } \\
(\mathrm{m} l)\end{array}$ & $\begin{array}{c}\text { Total } \\
\text { protein } \\
(\mathrm{mg})\end{array}$ & $\begin{array}{c}\text { Total } \\
\text { activity } \\
(\mathrm{U})\end{array}$ & $\begin{array}{c}\text { Specific } \\
\text { activity } \\
(\mathrm{U} / \mathrm{mg} \cdot \mathrm{prot} .)\end{array}$ & $\begin{array}{c}\text { Yield } \\
(\%)\end{array}$ & $\begin{array}{c}\text { Purification } \\
\text { (-fold) }\end{array}$ \\
\hline Crude (Culture supernatant) & 1,350 & 12,825 & $5.22 \times 10^{4}$ & 4.0 & 100 & 1 \\
Acetone fractionation & 44 & 484 & $1.15 \times 10^{4}$ & 47.5 & 22.0 & 11.6 \\
Gelfiltration on Sepharose CL-6B & 189 & 88.5 & $1.01 \times 10^{4}$ & 113 & 19.3 & 27.8 \\
Solubilization and Supercentrifug. & 9.5 & 46.0 & $6.01 \times 10^{3}$ & 131 & 11.5 & 32.0 \\
Chromatography on DEAE-Sephacel & 9.0 & 7.29 & $3.41 \times 10^{3}$ & 467 & 6.53 & 115 \\
\hline
\end{tabular}

protein failed to pass through the absorbent and stayed at the top of the column. That is, the disaggregation of the enzyme protein was required prior to the ion-exchage chromatography.

A Similar phenomenon was reported on the particle fraction from Bacteroides melaninogenicus by Hausmann and Kaufman. ${ }^{20)}$ Their attempts to disaggregate and to release collagenase activity were unsuccessful. We have also tried to disaggregate collagenase active fraction with detergents for further purification. For ion-exchange chromatography, only non-ionic detergents such as Triton $\mathrm{X}, \mathrm{N}$ D-gluco-N-methylalkyanamide compounds, and alkyl- $\beta$-D-glucosides were useful. Among the detergents we tried, $0.8 \%$ Oct-Glu was the most effectve to disaggregate the enzyme without losing collagenolytic activity.

By taking advantage of the fact that the collagenolytic enzyme easily aggregates in the usual buffer, supercentrifugation of the gel filtrate was performed to concentrate the enzyme. The resulting sediment yielded more than $80 \%$ of the activity when it was solubilized in the buffer containing $0.8 \%$ Oct-Glu. After the solubilization, collagenolytic activity was recovered in the supernatant when the mixture was supercentrifuged again. The buffer for chromatography on DEAE-Sephacel also contained this detergent in order to avoid re-aggregation of the enzyme. As shown in the chromatographic pattern on DEAE-Sephacel of the extract (Fig. 1), the active fraction of collagenolytic enzyme was successfully eluated in the buffer containing $0.2 \mathrm{M} \mathrm{NaCl}$. Through these purification procedures, collagenolytic enzyme was purified 115 -fold with a specific activity of $7.30 \times 10^{4} \mathrm{dpm}$ per mg protein.

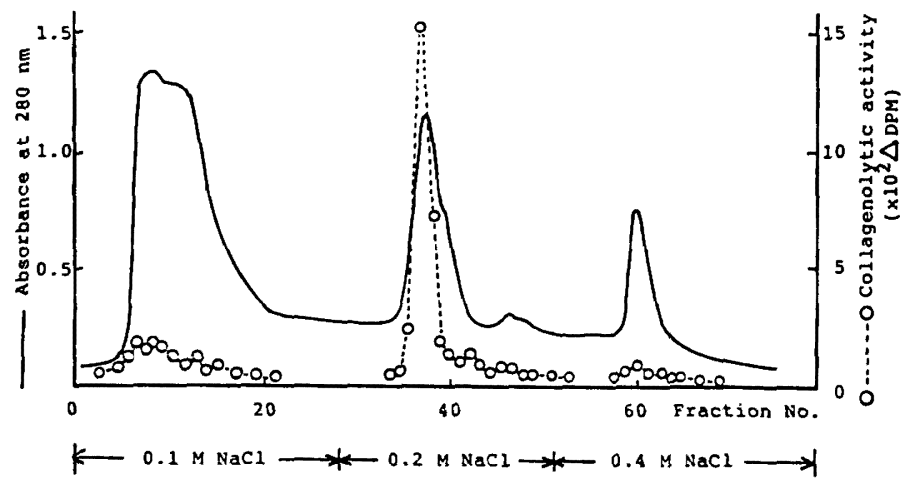

Fig. 1 Column chromatography of the solubilized enzyme sample with 1 O-N-octyl- $\beta$-D-glucopyranoside on DEAE-Sephacel. Elution was carried out in a stepwise manner by successive addition of $0.1,0.2$, and $0.4 \mathrm{M} \mathrm{NaCl}$ in $10 \mathrm{mM}$ Tris. $\mathrm{HCl}$ buffer, containing $1 \mathrm{mM}$ DTT and $0.8 \%$ 1-O-N-octyl- $\beta$-glucopyranoside. The flow rate was adjusted to $30 \mathrm{~m} l / \mathrm{h}$ and $6 \mathrm{~m} l$ fractions were collected. 
In order to determine the homogeneity of the purified sample, electrophoresis on polyacrylamide gel (PAGE) was performed according to the method of Davis. ${ }^{21)}$ The purified enzyme easily re-aggregated and could not be electrophoresed without sodium dodecyl sulfate (SDS) when the Oct-Glu was removed from the enzyme solution. An Attempt to replace SDS with Oct-Glu in the solution for PAGE was unsuccessful and resulted in tailings of the sample proteins. Therefore, electrophoresis with SDS was achieved. Although not shown in the Figure, the partially purified enzyme still had several bands on SDS-PAGE. However, there is no way to know if these bands were of collagenolytic enzyme or contaminated proteins, because treatment of collagenolytic enzyme with SDS totally inactivated the activity irreversibly.

Isoelectric focusing of the partially purified enzyme was carried out with a $110 \mathrm{~m} l$ column (LKBProdukter, Bromma, Sweden) by the method of Vesterberg and Svensson, ${ }^{22}$ using $1 \%$ ampholite with a $\mathrm{pH}$ range from 3 to 10 in a sucrose gradient. As shown in Fig. 2, most of the enzyme protein was focused at pI 4.4, but some activity was found also at the fraction of pI 5.5. Some other protein peaks which had no collagenlytic activity were also found. This result suggests that the partially purified collagenolytic enzyme still had contaminated proteins and might have some isoenzymes.

In our previous paper," some effects of crude collagenolytic enzyme in the culture medium of $B$.

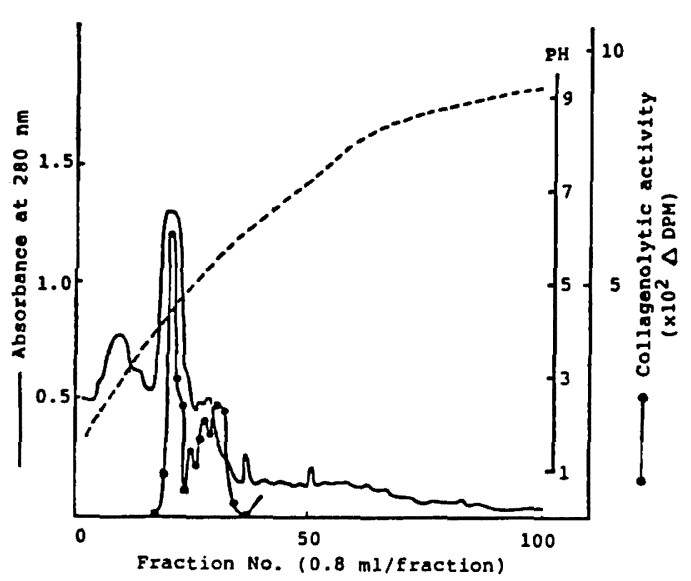

Fig. 2 Isoelectric focusing of the partially purified collagenolytic enzyme. A portion of partially purified material (approximately $3.0 \mathrm{mg}$ protein) was subjected to a 110 $\mathrm{ml}$ column with $1 \%$ ampholite of a $\mathrm{pH}$ range from 3 to 10 in a sucrose gradient. The run was performed at a voltage of $350 \mathrm{~V}$ for $40 \mathrm{~h}$.

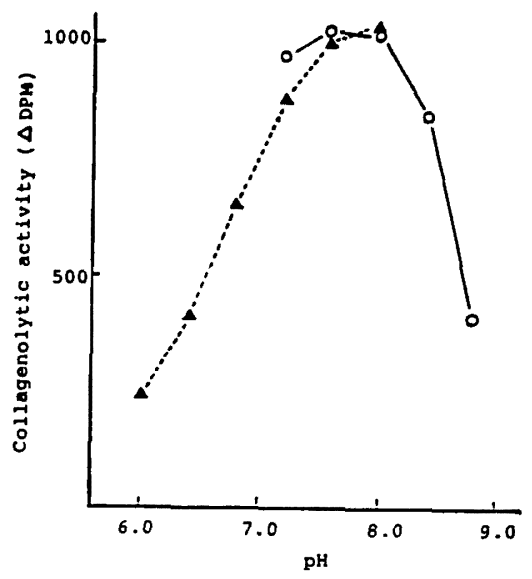

Fig. 3 PH dependency of the partially purified collagenolytic enzyme. Two kinds of buffers were used for this experiment, $0.1 \mathrm{M}$ Tris-maleate buffer ( $\mathrm{pH} 6.0-8.0$, $\Delta--\Delta)$ and $0.1 \mathrm{M}$ Tris- $\mathrm{HCl}$ buffer (pH 7.2-8.8, O-

gingivalis on reducing agents having thiol-groups and thiol-blocking reagents were described. Although it is not shown in the Table, partially purified enzyme showed the same effect on these reagents as that described previously" for the crude enzyme. Fig. 3 shows the pH-dependency on the activity of the partially purified collagenolytic enzyme. The dependency was studied using two kinds of buffers, $0.1 \mathrm{M}$ Tris-maleate $(\mathrm{pH} 6.0-8.0)$ and $0.1 \mathrm{M}$ Tris- $\mathrm{HCl}(\mathrm{pH} 7.2-8.8)$ in the reaction mixture. The enzyme had optimum activity at a $\mathrm{pH}$ range from 7.6-8.0 in Tris- $\mathrm{HCl}$ buffer.

Human $\alpha_{2}$-macroglobulin is a common inhibitor of all kinds of proteinases including specific collagenase of mammalian origin. ${ }^{233}$ The inhibition of specific collagenase is caused by the interaction of 
collagenase and $\alpha_{z}$-macroglobulin. ${ }^{24)}$ Furthermore, some human serum components interact with some oral anaerobes including $B$. gingivails and aggregate bacterial cells including $B$. gingivalis. ${ }^{14,25)}$ Therefore, the inhibitory effect of some serum components on the collagenolytic enzyme from $B$. gingivalis was determined. Table 2 summarizes the inhibition of the partially purified collagenolytic enzyme by some serum components as the concentration in the reaction mixture which produced $50 \%$ inhibition (IC 50 ). The activity of the partially purified enzyme was strongly inhibited by not only globulin fractions but also by albumin. The inhibition by rabbit albumin was stronger than that by globulin
Table 2 Effect of some serum components on collagenolytic enzyme isolated from Bacteroides gingivalis

\begin{tabular}{lc}
\hline \multicolumn{1}{c}{ Serum component } & $\mathrm{IC}_{50} *(\mathrm{mg} / \mathrm{m} l)$ \\
\hline Human $r$-globulin & 0.056 \\
Human $\alpha_{2}$-macroglobulin & 0.041 \\
Rabbit $\gamma$-globulin & 0.103 \\
Rabbit anti- $B$. gingivalis & \\
serum $r$-globulin & 0.092 \\
Rabbit albumin & 0.015 \\
\hline
\end{tabular}

* Concentration of serum component in the reac tion mixture which produced $50 \%$ inhibition. The value was obtained by plotting the data of at least four different concentrations on a logarithmic probit paper.

fractions. The inhibition of the enzyme by $\gamma$-globulin was non-speciffc. As shown in the Table, serum $r$-globulin prepared from immunized rabbit with $B$. gingivalis cells inhibited the collagenolytic enzyme at the same order as that from the unimmunized one.

The phenomenon that some serum components strongly inhibited the collagenolytic activity is of particular interest from the viewpoint of oral defence mechanisms. The deep gingival pockets where $B$. gingivalis resides are usually abundant in the exudate with some serum components. These serum components might be effective in decreasing the pathogenecity of $B$. gingivalis by inhibiting the collagenolytic activity of $B$. gingivalis.

\section{Acknowledgement}

This study was supported in part by a Grant-in-Aid for Scientific Research from the Ministry of Education, Science and Culture of Japan, 1986.

\section{References}

1) Nakamura, R., Littarru, G. P., Folkers, K. and Wilkinson, E. D.: 1974. Study of Co $Q_{10}$-enzymes in gingiva from patients with periodontal disease and evidence for a deficiency of coenzyme $Q_{10}$, Proceed. Natl. Acad. Sci. USA, 71; 1456, 1974.

2) Robertson, P. B. and Simpson, J.: Collagenase: Current concepts and relevance to periodontal disease, J. Periodont., $47 ; 29$, 1976.

3) Soderling, E. and Paunio, K. U.: Conditions of production and properties of the collagenolytic enzymes by two Bacillus strains from dental plaque, J. Periodont. Res., 16 ; 513-523, 1981.

4) Toda, K., Otsuka, M., Ishikawa, Y., Sato, M., Yamamoto, $Y$. and Nakamura, R. : Thiol-dependent collagenolytic activity in cu-
Iture media of $B$. gingivalis, J. Periodont. Res., 19 ; 372, 1984.

5) Otsuka, M., Ichimori, M., Sato, M., Yamamoto, Y. and Nakamura, R. : Extracellular protease from oral anaerobes, J. Dent. Hlth., $33 ; 190,1983$.

6) Yoshimura, F., Nishikawa, M., Suzuki, T., Hoover, C. I. and Newbrun, E. : Characterization of a trypsin-like protease from the bacterium Bacteroides gingivalis isolated from human dental plaque, Arch. Oral Biol., 29 ; 559, 1984.

7) Otsuka, M., Endo, J., Hinode, D., Nagata, A., Maehara, R., Sato, M. and Nakamura, R. : Isolation and characterization of protease from culture supernatant of Bacteroides gingivalis, J. Periodont. Res., 1987 (in press).

8) Berman, M. and Dohlman, C.: Collagenase inhibitors, Arch. d'Ophthalmol. (Paris), 35 ; 
95, 1975.

9) Woessner, J. F. Jr.: A latent form of collagenase in the involuting rat uterus and its activation by a serine protease, Biochem. J., $161 ; 535,1977$.

10) Murphy, G., Cartwright, E. C., Sellers. A. and Reynolds, J. J. : The detection and characterization of collagenase inhibitors from rabbit tissue in culture, Biochim. Biophys. Acta, 483 ; 493, 1977.

11) Uitto, V.-J. and Raeste A.-M. : Activation of latent collagenase of human leucocytes and gingival fluid by bacterial plaque, J. Dent. Res., 57 ; 844, 1978.

12) Tanner, A. C. R., Haffer, C., Bratthall, G. T., Visconti, R. A. and Socransky, S. S. : A study of the bacteria associated with advancing periodontitis in man, J. Clin. Periodont., 6 ; 278, 1979.

13) Slots, J. : Subgingival microflora and periodontal disease, J. Clin. Microbiol., 6 ; $351,1979$.

14) Slots, J.: Importance of black-pigmented Bacteroides in human periodontal disease. In: Host-Parasite Interactions in Periodontal Disease, Genco, R. J. and Mergenhagen, S. E., eds., American Society for Microbiology, Washington, DC, 1982, p. 27.

15) Holdeman, L. V., Cato, E. P. and Moore, W. E. C.: Anaerobic Laboratory Mannual, 4th edition, Anaerobic Laboratory, Virginia Polytechnic Institute and State University, Blacksburg, 1977, p. 144.

16) Bornstein, P. and Piez, K. A. : 1964. A biochemical study of human skin collagen and the relation between intra- and intermolecular cross-linking, J. Clin. Invert., 43 ; 1813, 1964.

17) Bornstein, P. and Piez, K. A. : 1966. The nature of the intramolecular cross-links in collagen. The separation and characterization of peptides from the cross-link region of rat skin collagen, Biochemistry, $5 ; 3460$, 1966.

18) Cawston, T. E. and Barrett, A. : A rapid and reproducible assay for collagenase using $1^{114} \mathrm{C}$ acetylated collagen, Analyt. Biochem., $99 ; 340,1979$.

19) Hartree, E. F. : Determination of protein : A modification of the Lowry method that gives a linear photometric response, Analyt. Biochem., 48 ; 422, 1972.

20) Hausmann, E. and Kaufman, E. : Collagenase activity in a particulate fraction from Bacteroides melaninogenicus, Biochim. Biophys. Acta, 194 ; 612, 1969.

21) Davis, B. J. : Disc electrophoresis-II. Method and application to human serum proteins, Ann. N. Y. Acad. Sci., 121 ; 405, 1964.

22) Vesterberg, O. and Svensson, H. : Isoelectric fractionation, analysis, and characterization of ampholites in natural $\mathrm{pH}$ gradients. IV. Further studies on the resolving power in connection with separation of myoglobulins, Acta Chim. Scand., 20; 820, 1966.

23) Sellers, A. and Murphy, G. : Collagenolytic enzymes and their naturally occurring inhibitors, Internat. Rev. Connective Tissue Res., 9 ; 151, 1981.

24) Werb, Z., Burleigh, M. C., Barrett, A. J. and Starkey, P. M.: The interaction of $\alpha_{2}$-macroglobulin with proteases. Binding and inhibition of mammalian collagenases and other metal proteases, Biochem. J., 139 ; $359,1974$.

25) Hammond, B. F. and Stevens, R. H. : 1982. Capnocytophaga and Actinobacillus actinomycetemcomitans: Occurrence and pathologic potential in juvenile periodontitis. In : Host-Parasite Interactions in Periodontal Diseases, Genco R. J, and Mergenhagen, S. E. eds., American Academy for Microbiology, Washington, DC, 1982, p. 46. 